\title{
Р.В. Писик
}

\section{ОСОБЛИВОСТІ ЛЕКСИЧНОЇ АНТОНІМІЇ АРАБСБКОЇ МОВИ}

$\mathrm{O}$ дним 3 найважливіших проявів системних відносин у мові та мисленні є явище лексичної антонімії. Оскільки антонімія є однією з мовних універсалій, вона представлена і в лексико-семантичній системі арабської мови, однак має свою специфіку. 3'ясування особливостей цього явища в арабській мові не лише сприятиме кращому розумінню семантичних властивостей лексичних одиниць арабської мови, природи системності в арабській лексиці, а й допоможе у перекладацькій діяльності, тому що часто антонімічний переклад - єдиний вихід здійснити мовні трансформації без втрати конотативних відтінків. Дослідження лексичної антонімії в арабській мові є важливим не лише 3 лінгвістичного, а й з комунікативного боку, бо це явище $є$ найкращим способом дати вичерпну характеристику дійсності за допомогою контрастності.

Існує чимало арабських мовознавчих праць, які б висвітлювали питання лексичної антонімії, поряд з тим спостерігаємо практичну відсутність аналогічних вітчизняних досліджень. У праці “Арабская лексикология” [Белкин 1975] поряд з розгорнутими викладами таких тем, як “Синонімія”, “Полісемія”, “Омонімія”, автор лише побіжно згадує про енантіосемію в арабській мові [Белкин 1975, 10], а це явище, як ми знаємо, $є$ похідним від антонімії. Найновіші статті зазначеної проблематики - це "Antonyms in arabic are a strange phenomenon" [Tamim al-Barghouti] та [رفيف هلال]. У першій зроблено спробу пояснити причину появи енантіосемічних слів в арабському лексиконі, а в другій здійснено класифікацію арабських антонімічних одиниць [رفيف هلال. Однак досі залишаються невирішеними питання про найзагальніші особливості антонімії в арабській мові, які б продемонстрували різницю вияву цього явища в арабській мові від інших мов. Саме тому основне завдання статті - це спроба з'ясувати такі невирішені раніше питання зазначеної проблеми, як відношення між компонентами арабських антонімічних пар на основі аналізу лексики, антонімічні можливості різних частин мови, структура арабських антонімів, неантонімічна лексика в арабській мові, взаємозв'язок між антонімами та енантіосемія як особливе лексико-семантичне явище.

Загальноприйнятим є розуміння антонімії як мовного явища, вираженого протилежними за значенням одиницями мови, що служать для позначення протилежних односуттєвих явищ об'єктивної реальності. Є. Міллер ствердує, що “між антонімами існує тісний семантичний зв'язок, який має концептуальну природу - предметно-речові позначення ототожнених контрастів викликають у свідомості найбільш сталі асоціативні зв'язки" [Миллер 1983, 65]. Отже, антоніми - це слова з протилежними значеннями, що виражають несумісні поняття.

Арабські граматисти трактують антонімію (مُّنَ) як “протиріччя, що виникає між

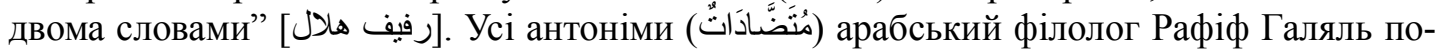
ділив на чотири розряди [رفيف هلال], поклавши в основу своєї класифікації тип протиставлення у семантичному відношенні:

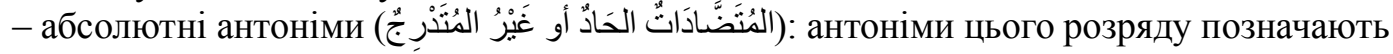
два видові поняття, які разом становлять певне родове поняття, градація між якими $\epsilon$

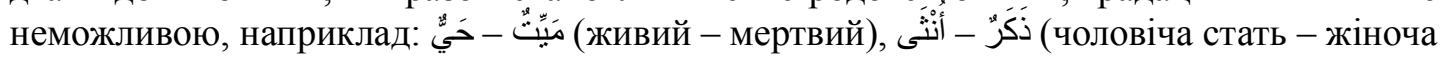




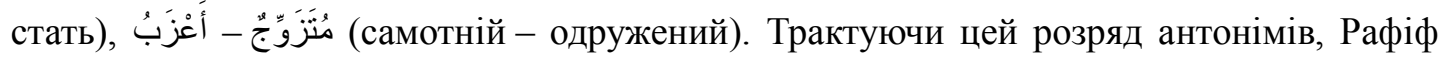
Галяль вдається до логічних аргументів, стверджуючи, що між поняттями, які виражають ці слова, не може бути чогось середнього, що поєднувало б ознаки обох понять [رفيف هلال

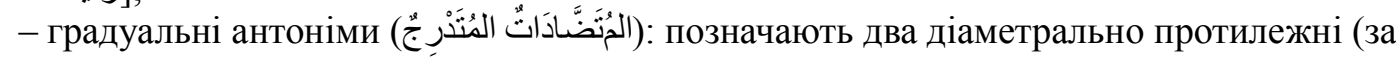
мірою або ступенем вияву) видові поняття певного родового поняття. Таке родове поняття характеризується можливістю ступеневого зростання або спаду, відповідні антоніми не повністю взаємовиключають один одного, і тому між крайніми виявами поняття можливі проміжні ланки, а заперечення одного 3 таких антонімів не є ствер-

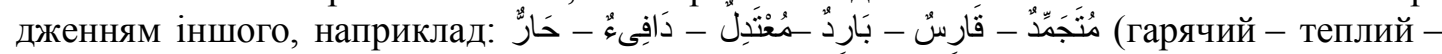
помірний - холодний - студений - крижаний). Ці середні проміжні поняття також називають мезонімами [Сучасна українська мова 2008, 63];

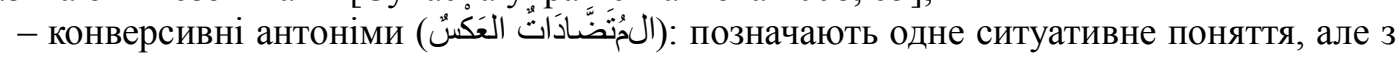
різних сторін. Такі антоніми вказують на існування симетрії в понятті, тобто ці антоніми не просто заперечують один одного, а взаємопередбачають свою появу в нашій

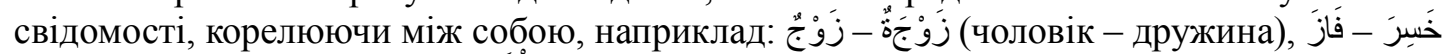
(перемагати - програвати), بَاعَ - إِثْنَرَى (продавати - купувати);

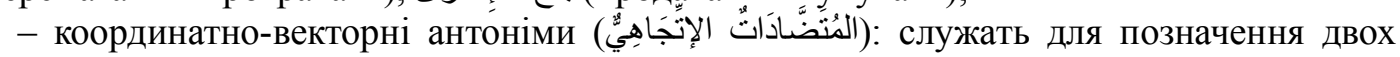
протилежно спрямованих або зворотних дій, явищ, напрямків, відношень чи позначаџють дві протилежні точки певного просторового або часового відрізка, наприклад:

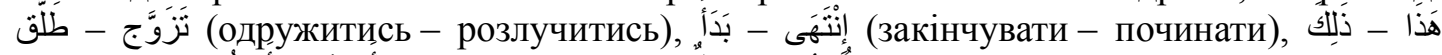

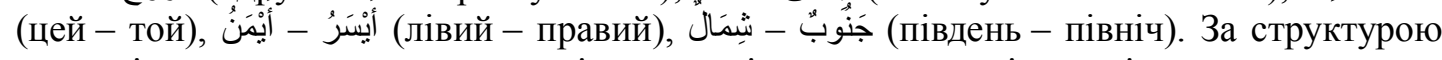
опозиції, а саме можливою наявністю проміжного члена, ці антоніми нагадують гра-

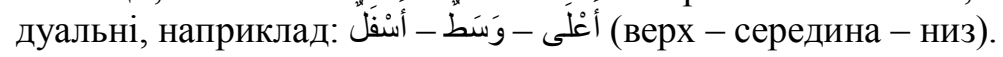

Аналізуючи лексику арабської мови, ми зауважили, що між антонімічними парами

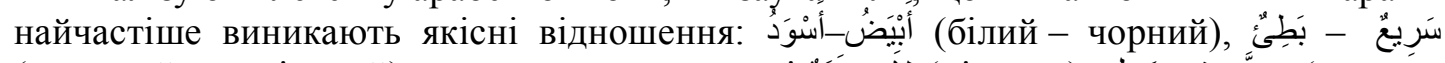

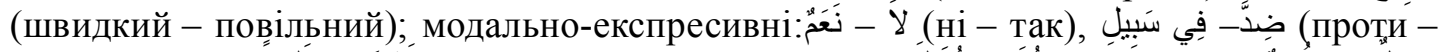

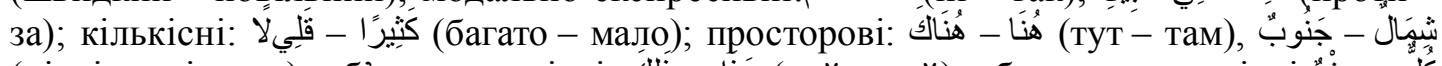

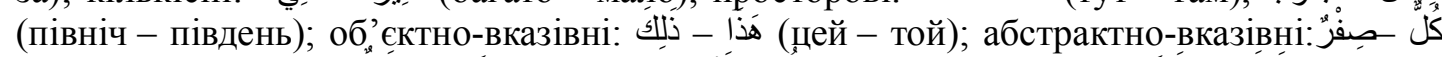

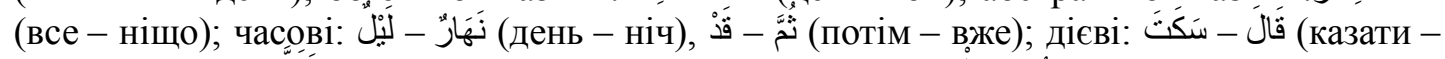

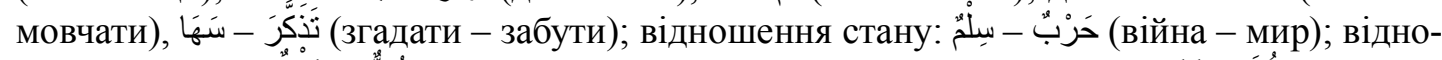

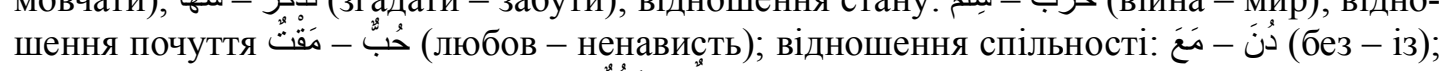
відношення стосунків між людьми: صَدِيقُ - عَدُو (друг - ворог).

3 точки зору класичної арабської морфології [Гранде 2001, 116-120] здатність різних частин мови вступати в антонімічні зв'язки можна охарактеризувати таким чином:

- імена: а) власне іменник - серед іменників антонімами в арабській мові найчастіше бувають ті, що називають абстрактні поняття: 1) антоніми, які вказують на якість: سُرُور - حُزْنْ (радість - сум); 2) антоніми, які вказують на опредмечену дію й утворені від

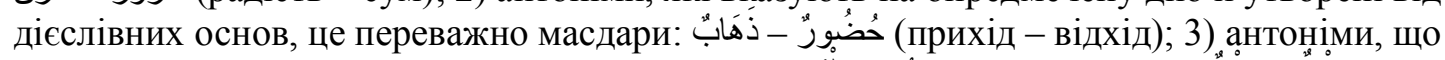

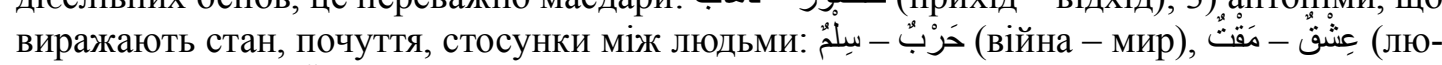
бов - ненависть). Їхня поява в арабській мові здебільшого зумовлена дієслівними основами. Конкретних іменників серед антонімів арабської мови мало. Вони, як правило, також співвідносні з абстрактними поняттями: صَدِيقق - عَدُو (друг - ворог);

б) якісні прикметники - їхні антонімічні можливості очевидні, тому що якість най-

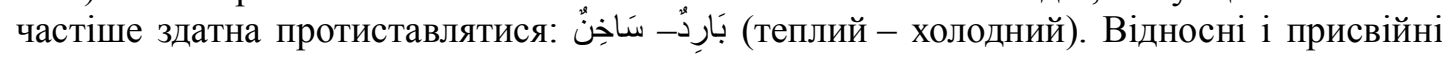
прикметники антонімами бувають рідко, їхня антонімічність диктується наявністю відповідних іменників: صَسَائِيٌ - صَبَاحِيٌ (вечірній - ранковий);

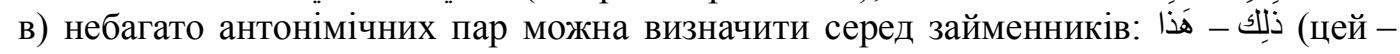
той);

г) антонімія прислівників в арабській мові широко представлена і визначається в основному антонімією тих частин мови, від яких вони утворені: صَبَاحًا - (вранці ввечері); 
- дієслово: ця частина мови найяскравіше репрезентує лексичну антонімію в арабській мові, оскільки, з одного боку, в ній основу лексичного складу становлять дієслівні корені, а з другого - це зумовлено внутрішніми закономірностями специфіки дієслова як частини мови - здатністю більшості дієслів не лише називати певну дію, а й передбачати процес, зворотний до названого;

- службові частини мови: в арабській мові трапляються антоніми і серед приймен-

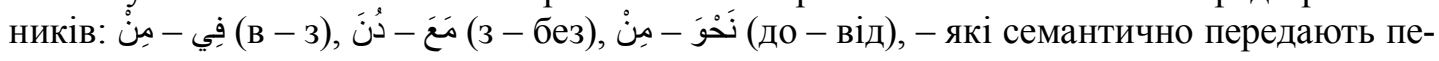
реважно просторові та хронологічні протиставлення.

Незважаючи на те що антонімію в арабській мові репрезентують усі частини мови, все ж, і це логічно, є пласти лексики, семантична природа яких не допускає, щоб вони вступали в антонімічні зв'язки. До лексичних одиниць, що не мають антонімів, належать:

а) власні назви - حَنَانُ, أَقَْاهَرَزة (Каїр, Ханан);

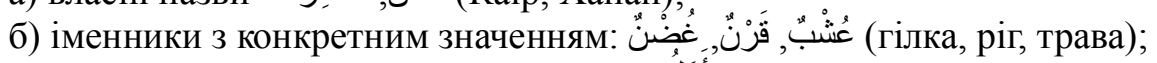

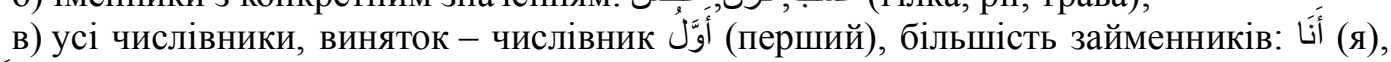
نحُ (ми);

г) галузеві (мовознавчі, хімічні тощо) вузькоспеціальні терміни: "ضَ (займенник), حَض (кислота);

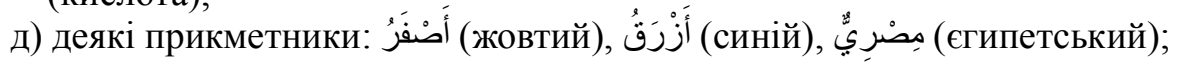

е) дієслова, що називають переважно конкретні дії та не передбачають протилежних процесів: قَرَ (читати), رَقَصَ (танцювати);

є) службові слова: وَ (i), أوَ (або), (чи).

Формально-структурний аналіз антонімів арабської мови засвідчує, що більшість антонімів є різнокореневими. Проте, подібно до української, в арабській мові застосовуються аналітичні способи передачі протилежності. Якщо в різнокореневих антонімах протилежність виражена різними коренями та семантикою, що закладена в них, то в однокореневих показником протилежності є додавання до слова допоміжних слів або часток заперечної конотації. Тому для того, щоб передати певні поняття, які, наприклад, в українській мові пишуться із префіксами (не-, без-, анти-, контр-, ip-, а-, де-, дез-), в

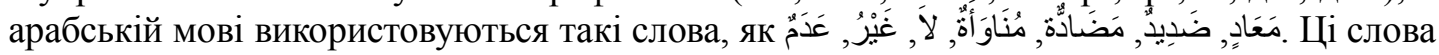
в основі своєї семантики містять елемент заперечення і в поєднанні $з$ певним словом утворюють лексикалізовані словосполучення зі значенням, протилежним до слів, від

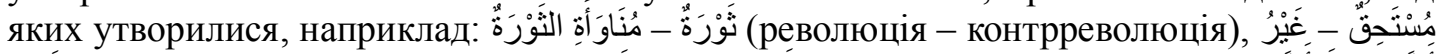

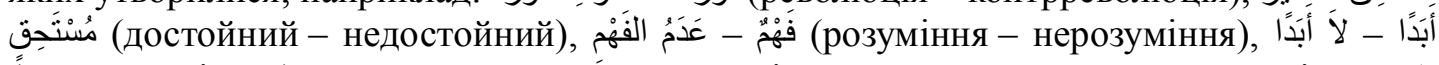
(завжди - ніколи). У випадку родових кореляцій для вираження протилежності в арабській мові до слова додається закінчення ӧ-, але утворення антонімів цим способом допускають далеко не всі слова. Часто при додаванні цього закінчення слово набуває

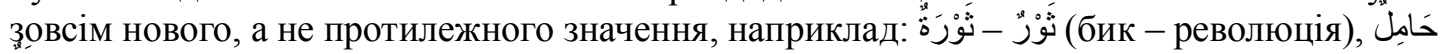
حَمِلة (вагітна жінка - авіаносець). Цим способом можна утворити антоніми до назв про-

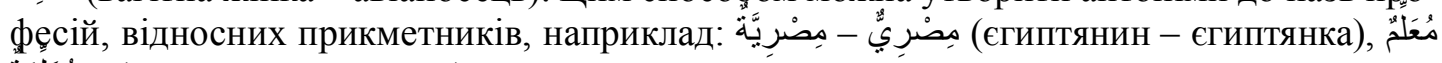
定 - (вчитель - вчителька).

Арабські антонімічні пари демонструють міцний взаємозв'язок компонентів. Це засвідчує те, що дуже багато антонімічних пар утворені за одною словотвірною моделлю. Наприклад, у прислівникових антонімах переважають слова, утворені за формулами

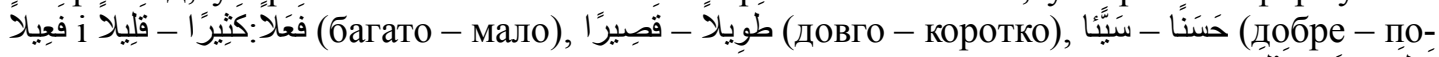

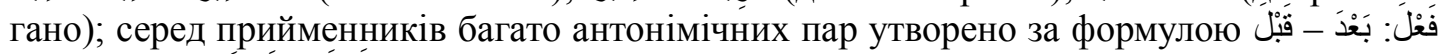

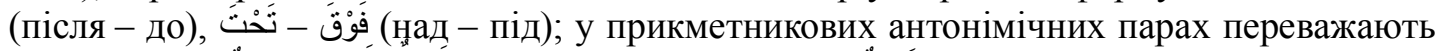

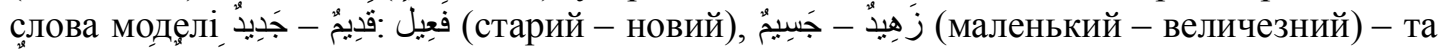

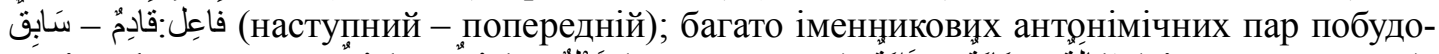

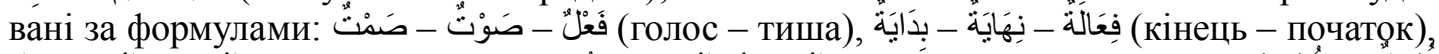

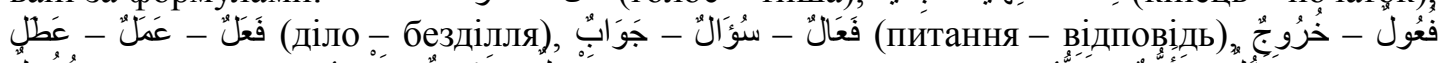

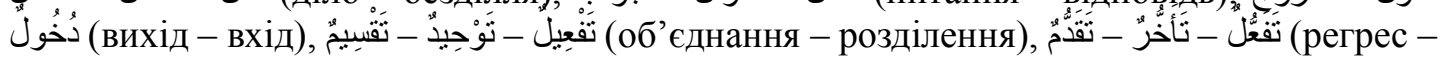




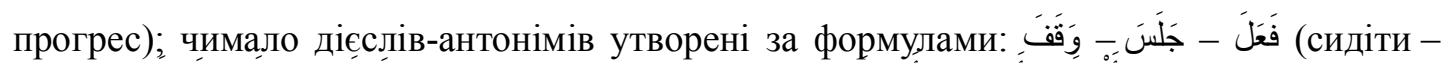

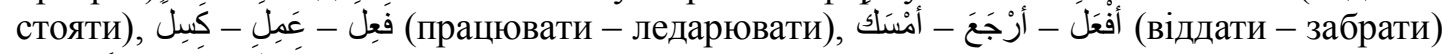

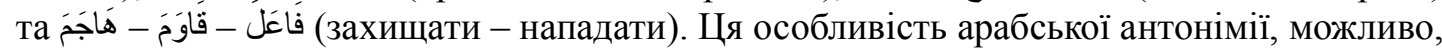
не має жодних закономірностей, однак кількість антонімічних пар, компоненти яких утворені за однаковою словотвірною моделлю, наштовхують на протилежну думку. Аналіз семантики та іiі категоріальних особливостей цих антонімів показує, що найчастіше однакова словотвірна модель $є$ в тих словах, які виражають абсолютну, різку протилежність. Тобто поняття, закладені в таких антонімах, не допускають жодних перехідних, посередніх градацій, ці антоніми повністю взаємозаперечують один одного. Можливо, саме це й зумовлює структуру антонімів. Найчастіше це явище виявляється в дієсловах та прикметниках.

Серед усіх названих рис арабської антонімії найбільш складним та суперечливим $€$ енантіосемічність. Енантіосемія (تُّ) - це мовне явище, коли в межах одного слова розвиваються антонімічні значення. Енантіосемія обумовлена законом мовної економії, системними відносинами в мові, дуалізмом людського мислення. Енантіосемічні мовні одиниці характеризуються наявністю єдиного плану вираження, двох планів змісту та антонімічного характеру відношень між ними. Такими словами в арабській мові $є$ : سَّلِّن (означає і здоровий, і вжалений змією, небезпечно поранений), بَِّير (i зрячий, і сліпий),

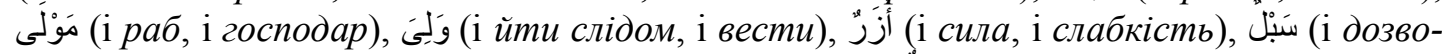
лений, і заборонений), حَمِ (i гаряча вода, і холодна), رَّ (i покращення, і погіршення),

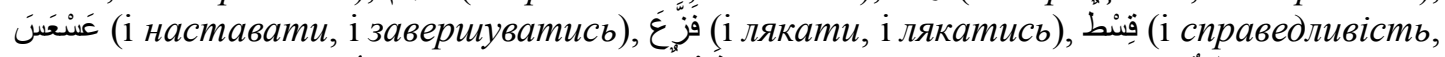

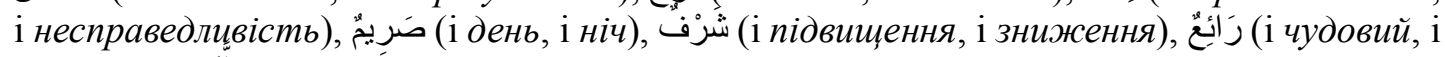
жахливий), جَل (i знімати шкіру, і оправляти в шкіру). Об'єктивно розмірковуючи про природу цього явища в арабській мові, можна сказати, що ці слова є дуже старими за своїм походженням, тому з часом у них почав відбуватись процес десемантизації первинного значення та неосемантизації, однак через ті чи інші обставини, наприклад через територію поширення цих слів, первинне значення повністю не стерлось, а друге, протилежне, вже встигло закріпитись. Тамім аль-Баргуті стверджує, що “як і багато інших властивостей арабської мови, причину цього пояснюють походженням мови бедуїнів - пустельні умови життя зумовлювали єдність, однорідність та рівність усіх та усього" [Tamim al-Barghouti 2004]. Тобто, на думку аль-Баргуті, процес загального зрівняння торкнувся й мови і її носії закріплювали непоєднувані поняття в одному слові. Відомо, що антонімічні значення в межах одного слова існують відносно недовго, “з часом вони можуть розпадатися, і слово вже має лише одне значення та більше не антонімічне самому собі” [Будагов 1965, 68].

Отже, явище лексичної антонімії яскраво представлене в арабській мові і пов'язане з відображенням однієї і тієї ж сутності з протилежних сторін. Між антонімами в арабській мові найчастіше встановлюються якісні, модально-експресивні, кількісні, просторові, об'єктно-вказівні, часові, дієві відношення, а також відношення стану, почуття, спільності, стосунків між людьми. Ці відношення зумовлені семантикою понять, які протиставляються. Серед специфічних рис антонімії в арабській мові- міцний взаємозв'язок компонентів антонімічних пар. Але існують питання, пов'язані з явищем лексичної антонімії, які все ще залишаються не до кінця вирішеними. Серед них - природа вищезгаданого зв'язку між антонімами, а також механізми набуття та втрати словами енантіосемічних значень. Таким чином, необхідно здійснити глибинний аналіз самого поняття антонімії, а також розмежовувати явища, характерні для мови, і явища, що виявляються в мові.

\section{ЛІТЕРАТУРА}

Баранов Х.К. Большой арабско-русский словарь: В 2 т. Москва, 2006.

Белкин В.М. Арабская лексикология. Москва, 1975.

Будагов Р.А. Введение в науку о языке. Москва, 1965.

Східний світ, 2013, № 1 
Гранде Б.М. Курс арабской грамматики в сравнительно-историческом освещении. Москва, 2001

Миллер Е.М. Межчастеречная антонимия. Саратов, 1983.

Сучасна українська мова: Підручник / О.Д. Пономарів, В.В. Різун, Л.Ю. Шевченко та ін. Київ, 2008.

Tamim al-Barghouti. Antonyms in Arabic are a strange phenomenon [Електронний ресурс] // The Daily Star. 2004. July 13. - Режим доступу до статті: http://arabicgems.wordpress.com/2006/04/21/ antonyms-in-arabic-are-a-strange-phenomenon/

مежим доступу до статті: http://wehda.alwehda.gov.sy/_archive.asp?FileName=34558250120080708142453 